\title{
A longitudinal community study: do psychosocial risk factors and child behavior checklist scores at 5 years of age predict psychiatric diagnoses at a later age?
}

Citation for published version (APA):

Kroes, M., Kalff, A. C., Steyaert, J. G. P. L. E., Kessels, A. G. H., Feron, F. J. M., Hendriksen, J. G. M., van der Aa-van Zeben, D. M. C. B., Troost, J., Jolles, J., \& Vles, J. S. H. (2002). A longitudinal community study: do psychosocial risk factors and child behavior checklist scores at 5 years of age predict psychiatric diagnoses at a later age? Journal of the American Academy of Child and Adolescent Psychiatry, 41(8), 955-963. https://doi.org/10.1097/00004583-200208000-00014

Document status and date:

Published: 01/01/2002

DOI:

10.1097/00004583-200208000-00014

Document Version:

Publisher's PDF, also known as Version of record

Please check the document version of this publication:

- A submitted manuscript is the version of the article upon submission and before peer-review. There can be important differences between the submitted version and the official published version of record.

People interested in the research are advised to contact the author for the final version of the publication, or visit the DOI to the publisher's website.

- The final author version and the galley proof are versions of the publication after peer review.

- The final published version features the final layout of the paper including the volume, issue and page numbers.

Link to publication

\footnotetext{
General rights rights.

- You may freely distribute the URL identifying the publication in the public portal. please follow below link for the End User Agreement:

www.umlib.nl/taverne-license

Take down policy

If you believe that this document breaches copyright please contact us at:

repository@maastrichtuniversity.nl

providing details and we will investigate your claim.
}

Copyright and moral rights for the publications made accessible in the public portal are retained by the authors and/or other copyright owners and it is a condition of accessing publications that users recognise and abide by the legal requirements associated with these

- Users may download and print one copy of any publication from the public portal for the purpose of private study or research.

- You may not further distribute the material or use it for any profit-making activity or commercial gain

If the publication is distributed under the terms of Article 25fa of the Dutch Copyright Act, indicated by the "Taverne" license above, 


\title{
A Longitudinal Community Study: Do Psychosocial Risk Factors and Child Behavior Checklist Scores at 5 Years of Age Predict Psychiatric Diagnoses at a Later Age?
}

\author{
MARIËLLE KROES, M.D., ARIANE C. KALFF, M.SC., JEAN STEYAERT, M.D., ALFONS G.H. KESSELS, M.D., \\ FRANS J.M. FERON, M.D., JOS G.M. HENDRIKSEN, Ph.D., THEA M.C.B. vAN ZEBEN, PH.D., \\ JAAP TROOST, Ph.D., JELLE JOLLES, Ph.D., AND JOHAN S.H. VLES, Ph.D.
}

\begin{abstract}
Objective: To examine the extent to which certain risk factors in 5- to 6-year-old children predict later psychopathology in a population-based sample of children from the province of Limburg in the south of the Netherlands. Method: Of the 2,290 children of interest, 1,317 children were screened with the Child Behavior Checklist (CBCL) and psychosocial risk factors for these children were collected. On the basis of the $C B C L$ ratings, 403 children participated in the second stage in which, 1.5 years later, standardized child psychiatric information was obtained. Weighted logistic regression analyses were used to investigate predictors of psychopathology. Results: In separate analyses of specific types of child psychopathology, different risk factors emerged as significant. Low-level parental occupation and having foreign-born parents were predictive of conduct disorders, and living in a single-parent family and a having a life event were the most important predictors of mood and anxiety disorders. Furthermore, CBCL-based ratings at 5 to 6 years of age corresponded well with interview-defined diagnoses 1.5 years later. Conclusions: Investigation of psychosocial risk factors and $\mathrm{CBCL}$ scores at the age of 5 to 6 years could be helpful in predicting child psychopathology and could help identify children at risk, in order to provide them with timely attention. J. Am. Acad. Child Adolesc. Psychiatry, 2002, 41(8):000-000.

Key Words: predictors, psychopathology, community population.
\end{abstract}

Research into child development suggests that early recognition of problems and early intervention in families will lead to successful prevention programs (Hermanns and Leu, 1998). For this reason, it is of great interest to investigate the extent to which early psychosocial risk factors

Accepted April 2, 2002.

Au. query 1 From the Department of Neurology (Drs. Kroes, Hendriksen, Troost, and Vles), Department of Clinical Epidemiology and Medical Technology Assessment (Dr. Kessels), Department of Psychiatry (Dr. Steyaert), and Department of Pediatrics (Dr. van Zeben), University Hospital of Maastricht; the Department of Psychiatry and Neuropsychology, University of Maastricht (Ms. Kalff and Dr. Jolles); the Youth Health Care of the Municipal Health Center (Feron); and the Child Rehabilitation Center Franciscusoord (Dr. Hendriksen).

This study was supported by the University Hospital of Maastricht fund for outstanding and competitive clinical research, "Het Profileringsfonds"; the Prevention Foundation of the Netherlands; the Brain and Behavior Research Institute of the University of Maastricht; and the St-Clemens and Kan. Salden Foundations of the Netherlands.

Reprint requests to Dr. Kroes, University Hospital of Maastricht, Department of Neurology, P.O. Box 5800, 6202 AZ, Maastricht, the Netherlands; e-mail: mkroes@home.nl.

0890-8567/02/4108-0000 (C) 2002 by the American Academy of Child and Adolescent Psychiatry. predict later psychopathology in a community sample of young children.

Although most community studies of young children have focused on psychosocial risk factors for behavioral problems in general (Campbell, 1995; Kalff et al., 2001a), little is known about psychosocial risk factors for specific $D S M$-based diagnoses. This is mainly because there are relatively few methods for specifically evaluating younger children (Costello et al., 1996) and because information obtained from children of this age is considered unreliable (Edelbrock et al., 1985). An important exception in this field is the study of Lavigne et al. (1998), in which 2- to 9-year-old children were investigated for predictors of stability and change in psychiatric disorders, based on "best estimates." The authors concluded that family context (especially lower levels of family cohesion, more negative life events, and negative affect by mothers) contributed to the onset or maintenance of problems starting in preschool years. A limitation of this study, however, is that it was not based on a community sample. Furthermore, 
only complex disruptive and emotional disorders were investigated and no attention was paid to risk factors for individual DSM diagnoses.

Many of the studies involving older children have focused on one single diagnosis (e.g., anxiety), rather than multiple diagnoses, or they have used an indicator for case versus noncase as the dependent variable (Lavigne et al., 1998; Manassis and Hood, 1998; Verhulst et al., 1985). Moreover, the studies failed to provide information on the specificity of the identified risk factors. The results of the studies that did focus on separate diagnoses have not been consistent. For example, Velez et al. (1989) concluded that the risk factors studied were related more to the externalizing than to the internalizing diagnoses, whereas Williams et al. (1990) failed to provide strong support for differences in background characteristics among children with different diagnoses. For this reason, additional research is needed to increase our knowledge of the predictive value of psychosocial risk factors in young children.

The first aim of the present report was to investigate whether various psychosocial risk factors (child, family, and environmental factors) in 5- to 6-year-old children are related to psychopathology in a general population of Dutch schoolchildren. Concerning the child-related factors, Velez et al. (1989) reported that stressful life events are important risk factors for both internalizing and externalizing disorders. Low-level parental occupation (Campbell, 1995; Kalff et al., 2001a), family size (Williams et al., 1990), race (Costello et al., 1996), family structure (Velez et al., 1989), low maternal age at delivery (Orlebeke et al., 1998), and maternal depression (Lavigne et al., 1998) are important family-related risk factors. Although the environment in which a child grows up is a potential risk factor for behavioral problems (Kalff et al., 2001b), little is known about its influence on DSM-based diagnoses (Hermanns and Leu, 1998). Data were collected during a longitudinal population study in the south of the Netherlands, titled the Study of Attention Disorders in Maastricht (SAM), that used a two-stage design (Kalff et al., 2001a; Kroes et al., 2001). In the first stage, the children were screened with the Child Behavior Checklist (CBCL) (Verhulst et al., 1996) and psychosocial risk factors were obtained. In the second stage, 1.5 years later, more detailed psychiatric information was collected from selected children by means of a standardized interview.

Although several authors have explored the crosssectional relations between CBCL dimensions and DSMbased diagnoses (Biederman et al., 1993; Jensen et al.,
1993; Kasius et al., 1997), it has been argued that longitudinal studies are needed to clarify the utility of the CBCL in young children for predicting DSM-based diagnoses at a later age (Keenan et al., 1997). Thus an additional goal of this study was to examine the predictive value of the different subscales of the CBCL in stage 1 of the study for individual DSM-based diagnoses in stage 2 of the study.

\section{METHOD}

\section{Subjects and Procedure}

Stage 1: Months 1-9. In the first stage of the study, all parents of children in the second grade of normal kindergarten schools in the south of the province Limburg (the Netherlands) were approached by the Youth Health Care organization for participation in the study. This included all public schools in this region (private schools do not exist in the Netherlands) excluding those for special educational needs. The national organization is responsible for performing a periodic health examination of all the children. The average response rate is $98 \%$. The school doctors perform this examination, and under Dutch law they are allowed to use medical information anonymously for epidemiological research purposes. The initial sample comprised 2,290 children, and the parents of 1,317 children $(57.5 \%$; 699 boys and 618 girls; mean age $=5.87 ; \mathrm{SD}=0.41)$ granted permission for participation. Responders and nonresponders were compared for sex, age, and demographic factors such as parental occupation, nationality, family structure, and living area by randomly sampling 200 subjects from both groups. Information was obtained anonymously from the medical records of the Youth Health Care. No significant differences between the groups were found (see also Kroes et al., 2001; Table 1).

On the basis of the CBCL scores, which was completed by the parents of the children, three groups of children (total $N=452$ ) were selected for stage 2 of the study. Group E (externalizing group) consisted of children with CBCL Externalizing scale scores above the 90th percentile and/or with CBCL Attention Problems scale scores exceeding the 95 th percentile ( $n=173$ ). Group I (internalizing group) consisted of children with Internalizing scale scores above the 90th percentile and who were not members of the first group $(n=59)$. Thus children with high scores on the Internalizing and Externalizing scales were assigned to group E. Finally, each child in these two groups was matched for sex, age ( \pm 2 months), and school (urban versus nonurban) with a child whose CBCL total score was below the 90th percentile. This "normal group" (group N) consisted of 220 children. Psychosocial risk factors were collected for the three selected groups.

Stage 2: Months 15-25. Of the 452 children, the parents of 403 ( $89 \% ; 233$ boys and 170 girls) were interviewed with the Amsterdam Diagnostic Interview for Children and Adolescents (ADIKA) (Kortenbout van der Sluijs et al., 1993). Eleven percent $(n=49)$ of the children's parents refused further participation or had moved. Of these 403 children, 150 were originally assigned to group E, 54 to group I, and 199 to group $\mathrm{N}$. At the time of the interview, the children's ages ranged from 6.4 to 8.6 (mean $=7.1, S D=0.4$ ) years. In $89.6 \%$ of the cases the mother of the child was interviewed, in $6.4 \%$ of the cases the father, and in $4.0 \%$ of the cases another caretaker.

\section{Measures}

Stage 1. The CBCL was developed by Achenbach and Edelbrock (1983) and translated and revised by Verhulst et al. (1996) for the Dutch

\section{CHI August 2002, Kroes, article \#110218, 3 tables, 0 figures}


TABLE 1

Demographic Characteristics of Investigated Sample $(n=403)$ and Weighted Percents to Responder Group $(n=1,317)$

\begin{tabular}{|c|c|c|c|}
\hline Variable & $n$ & $(\%)$ & Weighted (\%) \\
\hline \multicolumn{4}{|l|}{ Live event } \\
\hline Yes & 94 & (24) & (19) \\
\hline No live event & 307 & (76) & $(81)$ \\
\hline Missing & 2 & $(0)$ & $(0)$ \\
\hline \multicolumn{4}{|l|}{ Parental occupation } \\
\hline High & 113 & $(28)$ & $(30)$ \\
\hline Middle & 105 & (26) & (29) \\
\hline Low & 178 & (44) & $(40)$ \\
\hline Missing & 7 & (2) & (1) \\
\hline \multicolumn{4}{|l|}{ Nationality } \\
\hline Dutch & 343 & $(85)$ & $(86)$ \\
\hline Foreign-born & 53 & (13) & (12) \\
\hline Missing & 7 & (2) & (2) \\
\hline \multicolumn{4}{|l|}{ No. of children } \\
\hline 1 & 66 & (16) & $(15)$ \\
\hline 2 & 232 & (58) & (59) \\
\hline$>2$ & 103 & $(26)$ & (26) \\
\hline Missing & 2 & $(0)$ & $(0)$ \\
\hline \multicolumn{4}{|l|}{ Position of child in sibship } \\
\hline 1 st & 199 & (49) & $(46)$ \\
\hline 2nd & 142 & (35) & (38) \\
\hline$>2 \mathrm{nd}$ & 54 & (14) & (14) \\
\hline Missing & 8 & (2) & (2) \\
\hline \multicolumn{4}{|l|}{ Family structure } \\
\hline Living with two parents & 336 & (83) & $(85)$ \\
\hline Living with one parent & 66 & (17) & (15) \\
\hline Missing & 1 & $(0)$ & $(0)$ \\
\hline \multicolumn{4}{|l|}{ Age mother at delivery } \\
\hline$>33 \mathrm{yr}$ & 73 & (18) & $(22)$ \\
\hline $27-33 \mathrm{yr}$ & 221 & (55) & $(56)$ \\
\hline$\leq 26 \mathrm{yr}$ & 108 & (27) & $(22)$ \\
\hline Missing & 1 & $(0)$ & $(0)$ \\
\hline \multicolumn{4}{|l|}{ Mental support mother } \\
\hline Yes & 57 & (14) & (11) \\
\hline No & 343 & $(85)$ & $(88)$ \\
\hline Missing & 3 & (1) & (1) \\
\hline \multicolumn{4}{|l|}{ Type of school } \\
\hline Education priority & 73 & $(18)$ & (15) \\
\hline No education priority & 330 & $(82)$ & $(85)$ \\
\hline \multicolumn{4}{|l|}{ Nursery after school hours } \\
\hline Yes & 47 & (12) & $(10)$ \\
\hline No & 353 & $(87)$ & (90) \\
\hline Missing & 3 & (1) & $(0)$ \\
\hline
\end{tabular}

population. The results of the questionnaire give a profile composed of nine problem scales (Withdrawn, Somatic Complaints, Anxious/Depressed, Social Problems, Thought Problems, Attention Problems, Delinquent Behavior, Aggressive Behavior, and Sex Problems), two broad-band scales (Externalizing, consisting of Delinquent and Aggressive Behavior; and Internalizing, consisting of Withdrawn, Somatic Complaints, and Anxious/Depressed), and the Total Problems score. Verhulst et al. (1996) defined both clinical and borderline cutoff values for the problem scales (clinical: $T>70$ [98th percentile], borderline T: 67-70 [95th-98th percentile]) as well for the total scores (clinical: $T>63$ [90th percentile], borderline T: 60-63 [82nd-90th percentile]).
Child characteristics, family variables, and environmental variables were recorded as psychosocial risk factors. There were three child characteristics: sex, age, and life events as elicited by means of an openended question. Categorizing these answers gives 55 health problems, 14 divorces, 6 (sexual) abuse, 10 loss of family member, and 9 other diverging answers. There were seven family variables. The first, level of occupational activity, was based on a full description of the parents' occupational activities and was coded according to the system used by the Dutch Central Bureau of Statistics. This code was then transformed to a 7-point scale, based on the mental complexity of the work, as rated by job experts (Directoraat-Generaal voor de Arbeidsvoorziening, 1989). It ranges from low skilled to academic labor and was divided into three levels for the current study: low (1,2, and 3), middle ( 4 and 5), and high (6 and 7). The other six family variables were country of birth of the parents, number of children, position of child in sibship, family structure, maternal age at delivery, and professional mental support for the mother (whether mother receives treatment for psychiatric or mental health problems). There were two environmental variables: (1) type of school the child attended (school with or without an educational priority policy: in the Netherlands schools with more children at risk, e.g., foreign-born, from one-parent families, receive more money from the government) and (2) nursery afterschool hours. Most of the information was collected from the medical records of the Youth Health Care, although information about life event, mental support, and nursery attendance was supplied by the parents themselves. Table 1 displays the distribution of the demographic characteristics of the group participating in the second stage $(n=403)$ and shows the weighted percentages.

Stage 2: Interview. The ADIKA (Kortenbout van der Sluijs et al., 1993) is the Dutch translation of the Diagnostic Interview for Children and Adolescents (DICA) (Herjanic and Campbell, 1977), which is based on the criteria of DSM-III-R (American Psychiatric Association, 1987). The criteria of DSM- $I V$ were used for diagnosing attentiondeficit/hyperactivity disorder (ADHD) (Westereich, internal publication, 1998). Five major domains of psychopathology were assessed: (1) ADHD $(n=35)$, which includes the inattentive, hyperactive, and combined type; (2) conduct/oppositional disorders $(n=93)$, which include conduct disorder and oppositional defiant disorder; (3) mood Au. query 2 disorders $(n=39)$, which encompass major depression, dysthymia (at present and past, with and without an underlying life event), and bipolar disorders; (4) anxiety disorders $(n=133)$, which include overanxious disorder, avoidant disorder, phobias, and posttraumatic stress disorder; and (5) elimination disorders $(n=66)$, which include functional enuresis and functional encopresis. These domains were based only on the ADIKA and not related to extra severity or impairment criteria. Although the Dutch version of the DICA-III-R interview has not been separately validated, the DICA and DICA-III-R have been demonstrated to have high test-retest reliability and moderate correlations with clinician-based diagnoses (Ezpeleta et al., 1996; Welner et al., 1987). Three skilled interviewers administered the ADIKAs. To optimize the reliability of the interview, the interviewers were trained and supervised intensively by a senior child and adolescent psychiatrist. The interviewers and the child and adolescent psychiatrist were blind to the CBCL screening results. Diagnoses were generated from the coded ADIKAs by a computer algorithm that ignores hierarchical $D S M$ criteria (Rozendaal, 1998).

\section{Statistical Analysis}

Because the selection procedure in stage 1 was based on the CBCL results, age, sex, and school, the selected group does not represent the entire responder group. For this reason, it was necessary to weight all analyses using the "sampling weight option" of STATA (StataCorp, 
2001), which permits adjustment for design characteristics such as two-stage sampling. The weights used were consistent with the inverse of the probability of selection, so the results can be interpreted as estimates appropriate for children in a community population.

To investigate which psychosocial risk factors at 5 to 6 years of age could predict different diagnoses according to the ADIKA 1.5 years later, logistic regression analyses were performed. In each regression analysis, the age and sex of the child at the moment of the ADIKA were entered as covariates. The other demographic variables were entered separately as well as simultaneously (multivariate logistic regression) as independent variables. To minimize lost cases in the analyses, separate categories were defined for missing items, for all different independent variables. Dependent variables were indicators for the five psychiatric domains mentioned in the previous section irrespective of comorbidity.

To examine the predictive value of different CBCL scales for later psychopathology, stepwise logistic regression analyses were used $(p<$ .05 ). Because of the hierarchical relationship of the nine CBCL syndrome scales, the Externalizing and Internalizing scales, and the Total Problems scale, it was deemed appropriate to perform regression analyses on the three different sets of variables. The first set included the nine subscales, the second set included the Externalizing and Internalizing scores, and the third set included the Total Problems score. This stepwise method makes it possible to calculate the predictive value of the different CBCL scales, as distinct from other CBCL scales. Cutoff points for the CBCL scales were chosen at borderline and clinical levels. The age and sex of the child were used as covariates.

\section{RESULTS}

\section{Psychosocial Risk Factors}

Risk factors were calculated for the five domains and for the category "any disorder." Table 2 presents the impact of the selected risk factors on these domains. Confidence intervals (CIs) are given for significant odds ratios (ORs). The occurrence of a life event was associated with ADHD, mood disorders, and anxiety disorders. Whereas low-level parental occupation was a risk factor for conduct disorders, middle-level parental occupation was protective, compared with a high-level occupation, against elimination disorders. Except for low-level parental occupation, children also were at risk of developing conduct disorders if their parents were foreign-born. Being an only child was associated only with anxiety disorders. Being from a single-parent family was a risk factor for the two internalizing domains, anxiety and mood disorders. Children of younger mothers were at risk for mood disorders and $\mathrm{ADHD}$, as were children whose mothers needed mental support. The most important risk factors that distinguished between children with and without any disorder were low-level parental occupation, single-parent family, and occurrence of a life event.

After multivariate logistic analyses (all variables were entered simultaneously), four of the five child psychiatric domains still had significant odds ratios, namely, ADHD, mood disorders, anxiety disorders, and any disorder. Significant risk factors were as follows: (1) life event $(\mathrm{OR}=4.6, \mathrm{CI}=1.5-13.6)$ for ADHD; (2) single-parent family $(\mathrm{OR}=4.7, \mathrm{CI}=1.9-11.7)$, younger mother $(<27$ years: $\mathrm{OR}=7.3, \mathrm{CI}=1.5-36.1 ; 27-33$ years: $\mathrm{OR}=7.6$, $\mathrm{CI}=1.8-31.8)$, life event $(\mathrm{OR}=4.3, \mathrm{CI}=1.4-13.4)$, and mental support of the mother $(\mathrm{OR}=3.0, \mathrm{CI}=1.1-8.7)$ for mood disorders; (3) being an only child (second position: $\mathrm{OR}=0.5, \mathrm{CI}=0.2-1.0$ ), older mothers (27-33 years: $\mathrm{OR}=0.4, \mathrm{CI}=0.2-0.8)$, and life event $(\mathrm{OR}=2.7, \mathrm{CI}=$ 1.4-5.3) for anxiety disorders; and (4) life event $(\mathrm{OR}=$ 2.9, $\mathrm{CI}=1.5-5.7)$ for any disorder.

\section{CBCL Scores as Predictors}

Table 3 shows the predictive value of the CBCL scores at 5 to 6 years of age for psychopathology 1.5 years later. The Aggressive Behavior subscale, the Externalizing scale, and the Total Problems scale of the CBCL were predictive of $\mathrm{ADHD}$ and conduct disorders. Attention problems were predictors of $\mathrm{ADHD}$ but not of conduct disorders.

Mood disorders and anxiety disorders were predicted by the Total Problems scale and the Internalizing scale; however, the different subscales of the CBCL were rather specific in being predictive for one of the two internalizing disorders. More specifically, the CBCL subscales Anxious/Depressed, Social Problems, and Thought Problems were predictive of mood disorders whereas Withdrawn and Sex Problems were predictive of anxiety disorders.

While the subscales Withdrawn and Delinquent Behavior were the best predictors of elimination disorders, borderline levels for Anxious/Depressed were associated with less frequent rates of this diagnosis. Elimination disorders were the only disorders not predicted by the Total Problems scale of the CBCL. Attention Problems, Withdrawn, and Aggressive Behavior were the major predictive subscales of the category "any diagnosis." In addition, the Externalizing and Internalizing scales and the Total Problems scale were predictors of "any diagnosis."

\section{DISCUSSION}

This article reports the results of a longitudinal community study of a large-population sample in the Netherlands. It describes the influence of psychosocial risk factors and CBCL scores at 5 to 6 years of age in relation to child psychiatric disorders 1.5 years later. Because diagnostic groups were nonexclusive (irrespective of comorbidity), 
TABLE 2

Weighted Odds Ratios ${ }^{a}$ (OR) and 95\% Confidence Intervals (95\% CI) for Child Psychiatric Domains in the Second Year of Primary School by Several Risk Factors in Year 1

\begin{tabular}{|c|c|c|c|c|c|c|}
\hline \multirow{2}{*}{$\begin{array}{l}\text { Psychosocial } \\
\text { Variables }\end{array}$} & ADHD & $\begin{array}{l}\text { Conduct } \\
\text { Disorders }\end{array}$ & $\begin{array}{c}\text { Mood } \\
\text { Disorders }\end{array}$ & $\begin{array}{c}\text { Anxiety } \\
\text { Disorders } \\
\end{array}$ & $\begin{array}{c}\text { Elimination } \\
\text { Disorders } \\
\end{array}$ & $\begin{array}{c}\text { Any } \\
\text { Disorder } \\
\end{array}$ \\
\hline & OR $(95 \% \mathrm{CI})$ & OR $(95 \% \mathrm{CI})$ & OR $(95 \% \mathrm{CI})$ & OR $(95 \% \mathrm{CI})$ & OR $(95 \% \mathrm{CI})$ & OR $(95 \% \mathrm{CI})$ \\
\hline \multicolumn{7}{|l|}{ Life event } \\
\hline No & 1.0 & 1.0 & 1.0 & 1.0 & 1.0 & 1.0 \\
\hline Yes & $4.5^{* *}(1.8-10.8)$ & 1.6 & $4.8^{* *}(1.9-12.0)$ & $2.8^{* *}(1.5-5.2)$ & 1.2 & $2.9^{* *}(1.5-5.5)$ \\
\hline \multicolumn{7}{|l|}{ Parental occupation } \\
\hline High & 1.0 & 1.0 & 1.0 & 1.0 & 1.0 & 1.0 \\
\hline Middle & 1.3 & 1.1 & 0.8 & 1.1 & $0.3^{*}(0.1-1.0)$ & 0.9 \\
\hline Low & 1.7 & $2.5^{*}(1.2-5.4)$ & 1.3 & 1.8 & 1.4 & $2.5^{* *}(1.4-4.6)$ \\
\hline \multicolumn{7}{|l|}{ Nationality } \\
\hline Dutch & 1.0 & 1.0 & 1.0 & 1.0 & 1.0 & 1.0 \\
\hline Foreign born & 0.8 & $2.8^{*}(1.2-6.7)$ & 0.8 & 1.3 & 0.6 & 1.1 \\
\hline \multicolumn{7}{|l|}{ No. of children } \\
\hline 1 & 1.0 & 1.0 & 1.0 & 1.0 & 1.0 & 1.0 \\
\hline 2 & 0.6 & 0.6 & 0.7 & $0.5^{*}(0.2-0.9)$ & 0.6 & 0.6 \\
\hline$>2$ & 0.4 & 1.2 & 1.0 & $0.4^{*}(0.2-0.9)$ & 0.8 & 0.6 \\
\hline \multicolumn{7}{|l|}{$\begin{array}{l}\text { Position of child } \\
\text { in sibship }\end{array}$} \\
\hline 1 st & 1.0 & 1.0 & 1.0 & 1.0 & 1.0 & 1.0 \\
\hline 2nd & 0.6 & 0.9 & 0.7 & $0.5^{*}(0.3-0.9)$ & 0.9 & 0.6 \\
\hline$>2$ nd & 0.2 & 2.2 & 1.5 & 0.7 & 0.9 & 1.0 \\
\hline \multicolumn{7}{|l|}{ Family structure } \\
\hline Two-parent & 1.0 & 1.0 & 1.0 & 1.0 & 1.0 & 1.0 \\
\hline Single-parent & 2.0 & 1.3 & $4.4^{* *}(1.8-10.5)$ & $2.3^{* *}(1.2-4.6)$ & 1.2 & $2.9^{* *}(1.4-6.2)$ \\
\hline \multicolumn{7}{|c|}{ Age mother at delivery ${ }^{b}$} \\
\hline$>33$ & 1.0 & 1.0 & 1.0 & 1.0 & 1.0 & 1.0 \\
\hline $27-33$ & 2.0 & 1.1 & $4.8^{*}(1.5-15.7)$ & 0.5 & 1.6 & 0.9 \\
\hline$\leq 26$ & $3.8^{*}(1.2-12.1)$ & 2.0 & $4.5^{*}(1.2-16.5)$ & 0.9 & 2.7 & 1.2 \\
\hline \multicolumn{7}{|l|}{ Mental support mother } \\
\hline No & 1.0 & 1.0 & 1.0 & 1.0 & 1.0 & 1.0 \\
\hline Yes & $3.6^{* *}(1.4-9.2)$ & 1.6 & $3.4^{* *}(1.4-8.4)$ & 0.8 & 0.7 & 1.9 \\
\hline \multicolumn{7}{|l|}{ Education } \\
\hline No priority policy & 1.0 & 1.0 & 1.0 & 1.0 & 1.0 & 1.0 \\
\hline Priority policy & 1.6 & 1.9 & 1.5 & 1.6 & 1.6 & $2.1^{*}(1.1-4.0)$ \\
\hline \multicolumn{7}{|l|}{ Nursery after school } \\
\hline No & 1.0 & 1.0 & 1.0 & 1.0 & 1.0 & 1.0 \\
\hline Yes & 2.2 & 0.9 & 0.7 & 1.8 & 1.1 & 1.4 \\
\hline
\end{tabular}

Note: ADHD = attention-deficit/hyperactivity disorder.

${ }^{a}$ Univariate logistic regression analyses adjusted for sex and age.

${ }^{b}$ Divided according to Orlebeke et al. (1998).

${ }^{*} p<.05 ;{ }^{* *} p<.01$.

it is not possible to draw conclusions for "pure" groups. However, this makes the study representative of psychopathology in the general population, in whom pure diagnoses are rarely made (Angold et al., 1999). To our knowledge this is one of the first reports of risk factors in relation to $D S M$-based diagnoses in young children, and the results are of interest because they could help to identify younger children at risk for psychopathology, which may improve our understanding of the etiology, the prognosis, and ultimately the prevention of mental disorders.

\section{Psychosocial Risk Factors}

The most important risk factors differentiating between children with and without disorders were low-level parental occupation, single-parent family, and occurrence of a life event. These risk factors are consistent with those found in other studies focusing on older children (Costello et al., 1996; Velez et al., 1989; Williams et al., 1990). However, although Williams et al. (1990) found that risk factors discriminated between children with and without disorders rather than between children with different disorders, our results identified unique risk factors for different child psychiatric domains.

For example, low-level parental occupation and foreignborn parents were associated with conduct disorders, and being an only child was associated with anxiety disorders. Furthermore, being from a single-parent family and the 
TABLE 3

Weighted Odds Ratios ${ }^{a}$ (OR) and 95\% Confidence Intervals (95\% CI) for Child Psychiatric Domains in the Second Year of Primary School by CBCL Scores in the First Year

\begin{tabular}{|c|c|c|c|c|c|c|c|}
\hline \multirow{2}{*}{$\begin{array}{l}\text { CBCL } \\
\text { Subscales }\end{array}$} & ADHD & $\begin{array}{l}\text { Conduct } \\
\text { Disorders }\end{array}$ & $\begin{array}{c}\text { Mood } \\
\text { Disorders } \\
\end{array}$ & $\begin{array}{c}\text { Anxiety } \\
\text { Disorders } \\
\end{array}$ & $\begin{array}{l}\text { Elimination } \\
\text { Disorders } \\
\end{array}$ & \multicolumn{2}{|c|}{ Any Disorder } \\
\hline & OR (95\% CI) & OR (95\% CI) & OR $(95 \% \mathrm{CI})$ & OR (95\% CI) & OR $(95 \% \mathrm{CI})$ & OR & (95\% CI) \\
\hline \multicolumn{8}{|l|}{ Withdrawn } \\
\hline \multicolumn{8}{|l|}{ Control } \\
\hline Borderline & & & & $11.8^{* * *}(4.1-34)$ & $3.5^{* *}(1.2-10.2)$ & $10.4^{* *}$ & $(2.1-52.6)$ \\
\hline Clinical & & & & $8.0^{* * *}(3.0-20.8)$ & & $7.4^{*}$ & $(1.5-36.8)$ \\
\hline \multicolumn{8}{|c|}{ Somatic Complaints } \\
\hline \multicolumn{8}{|c|}{ Control } \\
\hline \multicolumn{8}{|l|}{ Borderline } \\
\hline \multicolumn{8}{|c|}{ Clinical } \\
\hline \multirow{2}{*}{\multicolumn{8}{|c|}{$\begin{array}{l}\text { Anxious/Depressed } \\
\text { Control }\end{array}$}} \\
\hline & & & & & & & \\
\hline Borderline & \multicolumn{4}{|c|}{$\begin{array}{l}\text { Control } \\
\text { Borderline }\end{array}$} & $0.2^{*}(0.1-0.8)$ & & \\
\hline Clinical & & & $5.9^{* *}(1.5-22.6)$ & & & & \\
\hline \multicolumn{8}{|c|}{ Social Problems } \\
\hline \multirow{2}{*}{\multicolumn{8}{|c|}{$\begin{array}{l}\text { Control } \\
\text { Borderline }\end{array}$}} \\
\hline \multicolumn{5}{|l|}{ Borderline } & & & \\
\hline Clinical & & & $6.5^{*} \quad(1.3-32.9)$ & & & & \\
\hline \multicolumn{8}{|c|}{ Thought Problems } \\
\hline \multicolumn{8}{|c|}{ Control } \\
\hline Borderline & & & $9.3^{* *}(2.0-44.1)$ & & & & \\
\hline Clinical & & & & & & & \\
\hline Attention Prob & & & & & & & \\
\hline Control & & & & & & & \\
\hline Borderline & & & & & & & \\
\hline Clinical & $23.0^{* * *} \quad(5.5-96.1)$ & & & & & $7.7^{*}$ & $(1.0-59.0)$ \\
\hline Delinquent Be & & & & & & & \\
\hline Control & & & & & & & \\
\hline Borderline & & & & & & & \\
\hline Clinical & & & & & $4.1^{* *}(1.7-10.2)$ & & \\
\hline Aggressive Beh & & & & & & & \\
\hline Control & & & & & & & \\
\hline Borderline & & $10.5^{* * *} \quad(4.8-23.0)$ & & & & $2.7^{*}$ & $(1.2-6.1)$ \\
\hline Clinical & $16.3^{* * *} \quad(4.9-53.7)$ & $39.0^{* * *}(16.1-94)$ & & & & $15.2^{* * *}$ & $(3.3-69.1)$ \\
\hline Sex Problems & & & & & & & \\
\hline Control & & & & & & & \\
\hline Borderline & & & & $7.5^{* *} \quad(2.0-28.4)$ & & & \\
\hline Clinical & & & & & & & \\
\hline External & & & & & & & \\
\hline Control & & & & & & & \\
\hline Borderline & $82.0^{* * *}(12-543)$ & $9.5^{* * *}(13.9-54.6)$ & & & & & \\
\hline Clinical & $126^{* * *} \quad(29-538)$ & $27.5^{* * *} \quad(2.7-33.3)$ & & & $2.1^{*} \quad(1.2-3.8)$ & $6.5^{* * *}$ & $(3.6-11.7)$ \\
\hline Internal & & & & & & & \\
\hline Control & & & & & & & \\
\hline Borderline & & & & $2.9^{*} \quad(1.2-6.6)$ & & & \\
\hline Clinical & & & $4.1^{* * *}(1.9-9.1)$ & $6.1^{* * *}(3.6-10)$ & & $3.8^{* * *}$ & $(2.1-6.7)$ \\
\hline Total & & & & & & & \\
\hline Control & & & & & & & \\
\hline Borderline & & $5.8^{* * *} \quad(2.2-15.1)$ & & & & $2.8^{*}$ & $(1.2-6.5)$ \\
\hline Clinical & $34.1^{* * *} \quad(8.6-136)$ & $(7.5-28.8)$ & $3.3^{* *}(1.5-7.4)$ & $3.3^{* * *}(2.0-5.4)$ & & $8.0^{* * *}$ & $(4.6-13.8)$ \\
\hline
\end{tabular}

Note: $\mathrm{CBCL}=$ Child Behavior Checklist $\mathrm{ADHD}=$ attention-deficit/hyperactivity disorder.

${ }^{a}$ Stepwise logistic regression analyses adjusted for sex and age.

${ }^{*} p<.05 ;{ }^{* *} p<.01 ;^{* * *} p<.001$. 
occurrence of a life event were risk factors for the internalizing domains "mood disorders" and "anxiety disorders."

A possible explanation for this difference is that the earlier studies did not have sufficient statistical power. Williams et al. (1990) recognized that while their sample was large enough to distinguish between children with and without disorders, the groups of children with different disorders were too small to detect statistically significant differences between the different diagnoses. Our two-stage design had the advantage of generating high rates of different diagnoses.

It is interesting that the risk factors for ADHD (low maternal age, the occurrence of a life event, and mental support for the mother) were also risk factors for the internalizing domains. This finding may reflect the degree of comorbidity between ADHD and other (internalizing) disorders in our sample (Kroes et al., 2001).

The environmental risk factors (school with priority policy and nursery after school) were not significant predictors of later psychiatric diagnoses. In this study, the children who attended nursery after school were on average 5.9 years old. Furthermore, we did not classify how often children attended nursery after school, and thus detailed information on nursery attendance and age might give different results. Regarding schools with and without a priority policy, all odds ratios were positive but most were not significant. It is important, however, to mention that $p$ values were rather low and varied from 0.07 to 0.4 , which probably resulted in a significant contribution for "any disorder."

Controlling for potential confounding by multivariate logistic regression analyses strengthens the basis for causal inference. We found "life event" to be a stable risk factor that remained significant after multiple regression analyses for four domains. Most mentioned life events successively were health problems (55), divorces (14), loss of family member (10), (sexual) abuse (6), and others (9). It is important, however, to realize that experience of a life event was rather subjective and based on parental appraisal. On the other hand, multivariate regression analyses may also weaken potential associations. For this reason, these analyses should always be interpreted next to those of the univariate analyses. Concerning the univariate analyses, however, type I errors could have crept in because of the relatively high number of analyses done.

\section{CBCL Scores as Predictors}

In general, we can conclude that high scores on the CBCL at 5 to 6 years of age correlate well with interview- based diagnoses 1.5 years later. Whereas the CBCL is a suitable instrument to detect the presence of problem behavior in children aged 4-18 years (Verhulst et al., 1996), many $D S M$-based diagnoses are made after the age of 6 . Thus our results may be of clinical importance when young children are being studied. Although previous studies have shown the association between CBCLbased ratings and interview-defined diagnoses in older children (Chen et al., 1994; Kasius et al., 1997), these were all clinically based cross-sectional studies. Keenan et al. (1997) compared CBCL broad-band scales and psychopathology according to DSM-III-R in a community sample of 5-year-old children from low-income families. They found moderate but significant associations and recommended longitudinal studies to clarify the utility of the CBCL. This study is the first to investigate the predictive value of the $\mathrm{CBCL}$ in relation to interview-defined diagnoses in a prospective community study.

As found in other cross-sectional studies (Biederman et al., 1993; Chen et al., 1994; Kasius et al., 1997), the clinical range of Attention Problems predicted the DSMbased diagnoses of ADHD. While Aggressive Behavior was predictive for ADHD and conduct disorders, the subscale Delinquent Behavior was not. However, it is important to remember that a stepwise logistic regression analysis was used. This method identifies the best predictive subscales, which does not necessarily rule out the possibility that univariate analyses would show a significant correlation between Delinquent Behavior and conduct disorders. In the study of Kasius et al. (1997), stepwise analyses in a referred sample showed that delinquent behavior did predict conduct disorder $(\mathrm{OR}=71.9)$. This contradiction is probably due to the dissimilarity of the populations studied.

The odds ratios for the Internalizing subscales of the $\mathrm{CBCL}$ were considerably lower than those for the Externalizing subscales. This finding corresponds with that of Jensen et al. (1993), who found that the CBCL generally performed worse as a screening instrument for internalizing disorders. Finally, the subscale Withdrawn was predictive of a broad range of $D S M$-based disorders. These results are quite similar to those found by Kasius et al. (1997).

\section{Weighting Analyses}

In contrast to some other authors (Lavigne et al., 1998; Verhulst et al., 1985) who investigated risk factors in a two-stage design, we weighted our analyses. The advantage of doing this is that calculated odds ratios can be 
interpreted as applying to children in a community population, which in general will differ from odds ratios corresponding to the same predictors in a selected population. In a post hoc analysis, we reanalyzed the data without the "sampling weight option" of STATA (data not shown). Although in general the results were comparable, some important differences were noted.

The most important difference between weighted and unweighted analyses concerned the variable "younger age of the mother." In the unweighted analyses younger mothers were a significant risk factor for conduct disorders, a finding that disappeared after weighting of the analysis. In the weighted analyses, however, younger mothers became a significant risk factor for ADHD and mood

Au. query 3 disorder. Furthermore, having foreign-born parents appeared to be a significant risk factor for conduct disorder after weighting, whereas this was not the case for unweighted analyses. The results for the analyses with CBCL scores results were qualitatively the same, although generally the weighted odds ratios were slightly higher.

\section{Limitations}

Several comments must be made about the generalizability of our findings. First, our results reflect estimation for the entire responder group but not for the nonresponder group. Although the comparison of demographic factors between a random sample of 200 responders and nonresponders showed no significant differences, this does not necessarily mean conclusively that there are no differences between the groups. In addition, the low retention rate from the initial sample $(57.5 \%)$ must be mentioned as a limitation of the study. Furthermore, the population of interest in our study was living in the south of the province of Limburg. Although this part of the Netherlands is quite similar to the rest of the country in many ways, there are relatively fewer foreign-born families and relatively more highly educated inhabitants. Concerning generalization to other countries (e.g., the United States), we may assume that the direction of found associations would be the same because the investigated risk factors are "general" and do not bear only on Dutch children. However, what their exact impact would be for other cultures should be investigated.

The lack of multiple informants and measures of impairment are other limitations. In a previous study, we described prevalence estimates of DSM-based diagnoses and those in combination with severity criteria (Kroes et al., 2001). Rates decreased drastically, which did not allow us to examine the association of risk factors and these impaired diagnoses.

In addition, our study design prevented us from determining whether psychosocial variables and CBCL scores in stage 1 predict new cases of disorders or correlate with disorders that already existed at an earlier time frame. This limitation is inherent in such large-population studies. Nevertheless, the risk factors investigated can be of potential value by identifying children "at risk" because they do predict psychopathology 1.5 years later, whether this diagnosis is new or not.

\section{Clinical Implications}

Despite these limitations, this longitudinal community study of relatively young children increased our knowledge about relevant risk factors for various psychiatric diagnoses in a general population. In the Netherlands, it is common practice for school doctors to examine all 5- to 6-year-old children. The results of this study indicate that it would be valuable to use relevant psychosocial risk factors as well as CBCL questionnaires to help identify children at risk for different types of psychopathology. The results indicate that the CBCL may be a more important predictor than the psychosocial risk factors (higher odds ratios). On the other hand, we assume that psychosocial risk factors may play an important mediating role in the course of the disorder. When determining prevention or treatment interventions for individual children, however, it is important to interpret the relevance of risk factors and CBCL scores within the context of the results found during the examination of the child and the interview with the parents and teachers. Children with high-risk profiles could be monitored more extensively by the school doctor, but concrete interventions should be defined individually. Depending on the situation of the child, early support could be given at the school level (teacher training and support, remedial teaching, or reference for special education), at the family level (home video training or psychoeducation), and, when needed, via clinic-based treatment. We expect that these early interventions may prevent further difficulties.

\section{REFERENCES}

Achenbach TM, Edelbrock C (1983), Manual for the Child Behavior Checklist and Revised Child Behavior Profile. Burlington: University of Vermont Department of Psychiatry

American Psychiatric Association (1987), Diagnostic and Statistical Manual of Mental Disorders, 3 rd revised edition-revised (DSM-III-R). Washington, DC: American Psychiatric Association 
Angold A, Costello EJ, Erkanli A (1999), Comorbidity. J Child Psychol Psychiatry 40:57-87

Biederman J, Faraone SV, Doyle A et al. (1993), Convergence of the Child Behavior Checklist with structured interview-based psychiatric diagnoses of ADHD children with and without comorbidity. J Child Psychol Psychiatry 34:1241-1251

Campbell SB (1995), Behavior problems in preschool children: a review of recent research. J Child Psychol Psychiatry 36:113-149

Chen WJ, Faraone SV, Biederman J, Tsuang MT (1994), Diagnostic accuracy of the Child Behavior Checklist scales for attention-deficit hyperactivity disorder: a receiver-operating characteristic analysis. J Consult Clin Psychol 62:1017-1025

Costello EJ, Angold A, Burns BJ et al. (1996), The Great Smoky Mountains Study of Youth: goals, design, methods, and the prevalence of DSM-III$R$ disorders. Arch Gen Psychiatry 53:1129-1136

Directoraat-Generaal voor de Arbeidsvoorziening (1989), Handleiding voor de functie analyse (Manual Functional Analysis). The Hague: SDU Uitgeverij

Edelbrock C, Costello AJ, Dulcan MK, Kalas R, Conover NC (1985), Age differences in the reliability of the psychiatric interview of the child. Child Dev 56:265-275

Ezpeleta L, de la Osa N, Doménech JM, Navarro JB, Losilla JM (1997), Diagnostic agreement between clinicians and the Diagnostic Interview for Children and Adolescents-DICA-R-in an outpatient sample. J Child Psychol Psychiatry 38:431-440

Herjanic B, Campbell W (1977), Differentiating psychiatric disturbed children on the basis of a structured interview. J Abnorm Child Psychol 5:127-134

Hermanns J, Leu HR (1998), Family Risk and Family Support: Theory, Research and Practice in Germany and in the Netherlands. Delft, the Netherlands: Eburon

Jensen PE, Salzberg AD, Richters JE, Watanabe HK (1993), Scales, diagnoses, and psychopathology, I: CBCL and DISC relationships. J Am Acad Child Adolesc Psychiatry 32:397-406

Kalff AC, Kroes M, Vles JSH et al. (2001a), Factors affecting the relation between parental education as well as occupation and problem behaviour in Dutch 5- to 6-year-old children. Soc Psychiatry Psychiatr Epidemiol 36:324-331

Kalff AC, Kroes M, Vles JSH et al. (2001b), Neighbourhood-level and individual-level SES effects on child problem behaviour: a multilevel analysis. J Epidemiol Community Health 55:246-250

Kasius MC, Ferdinand RF, van den Berg H, Verhulst FC (1997), Associations between different diagnostic approaches for child and adolescent psychopathology. J Child Psychol Psychiatry 38:625-632
Keenan K, Shaw DS, Walsh B, Delliquadri E, Giovannelli J (1997), DSM-III$R$ disorders in preschool children from low-income families. $J$ Am Acad Child Adolesc Psychiatry 36:620-627

Kortenbout van der Sluijs MJ, Levita MJ, Manen de R, Defares BP (1993), ADIKA, Amsterdams diagnostisch interview voor kinderen en adolescenten. Lisse, the Netherlands: Swets \& Zeitlinger (available on www.swets.nl)

Kroes M, Kalff AC, Kessels AGH et al. (2001), Child psychiatric diagnoses generalized to a population of Dutch schoolchildren aged 6 to 8 years. $J$ Am Acad Child Adolesc Psychiatry 40:1401-1409

Lavigne JV, Arend R, Rosenbaum D, Binns HJ, Christoffel KK, Gibbons RD (1998), Psychiatric disorders with onset in the preschool years, II: correlates and predictors of stable case status. J Am Acad Child Adolesc Psychiatry 37:1255-1261

Manassis K, Hood J (1998), Individual and familial predictors of impairment in childhood anxiety disorders. J Am Acad Child Adolesc Psychiatry 37:428-434

Orlebeke JF, Knol DL, Boomsma DI (1998), Frequency of parental report of problem behavior in children decreases with increasing maternal age at delivery. Psychol Rep 82:395-404

Rozendaal N (1998), Handleiding computer algoritme ADIKA. Maastricht: Vakgroep Psychiatrie en Neuropsychology, Universiteit Maastricht (Department of Psychiatry and Neuropsychology, PO Box 616, 6200 MD Maastricht, the Netherlands)

StataCorp (2001), STATA: Software for Statistical Analyses, Release 7. College Station, TX: Stata Corporation

Velez CN, Johnson J, Cohen P (1989), A longitudinal analysis of selected risk factors for childhood psychopathology. J Am Acad Child Adolesc Psychiatry 28:861-864

Verhulst FC, Berden GF, Sanders Woudstra JA (1985), Mental health in Dutch children, II: the prevalence of psychiatric disorder and relationship between measures. Acta Psychiatr Scand Suppl 324:1-45

Verhulst FC, Ende van der J, Koot HM (1996), Handleiding voor de CBCL/4-18. Rotterdam, the Netherlands: Afdeling Kinder en jeugdpsychiatrie, Sophia Kinderziekenhuis/Academisch Ziekenhuis Rotterdam/Erasmus Universiteit Rotterdam

Welner Z, Reich W, Herjanic B, Jung KG, Amado H (1987), Reliability, validity, and parent-child agreement studies of the Diagnostic Interview for Children and Adolescents (DICA). J Am Acad Child Adolesc Psychiatry 26:649-653

Williams S, Anderson J, McGee R, Silva PA (1990), Risk factors for behavioral and emotional disorders in preadolescent children. J Am Acad Child Adolesc Psychiatry 29:413-419 


\section{JAACAP — Query Form}

\begin{tabular}{ll} 
Query \# & Query \\
\hline AQ1 & Please check footnotes carefully. Ms. Kalff correct? \\
AQ2 & Is "oppositional defiant disorder" correct? (we inserted "defiant") \\
AQ3 & Changed to "having foreign-born parents" - is this correct? \\
AQ4 & We changed this sentence to “... prevented us from determining ..." - is this correct? \\
AQ5 & Please confirm that the Clinical Implications section is acceptable as revised.
\end{tabular}

